CULTURAL

INTELLIGENCE 



\title{
CULTURAL INTELLIGENCE
}

\author{
Individual Interactions
}

Across Cultures

\section{P. CHRISTOPHER EARLEY}

SOON ANG

S T A N F OR D B USINESS B O OKS

An Imprint of Stanford University Press

Stanford, California 
Stanford University Press

Stanford, California

() 2003 by the Board of Trustees of the Leland Stanford Junior University. All rights reserved.

Printed in the United States of America on acid-free, archival-quality paper.

Library of Congress Cataloging-in-Publication Data

Earley, P. Christopher.

Cultural intelligence : Individual interactions across cultures / P. Christopher Earley and Soon Ang. p. $\mathrm{cm}$.

Includes bibliographical references and index.

ISBN 0-8047-4300-2 (cloth : alk. paper) — ISBN 0-8047-4312-6 (pbk. : alk. paper)

1. Leadership-Cross-cultural studies. 2. Social intelligence. 3. Social interaction. 4. ManagementCross-cultural studies. I. Ang, Soon. II. Title. HD57.7.E237 2003

$658.3^{\prime} 0089-\mathrm{dc} 21$

2003001558

Original Printing 2003

Last figure below indicates year of this printing:

1211

Designed by Andrew Ogus

Typeset by Classic Type in 10/13.5 Minion

Special discounts for bulk quantities of Stanford Business Books are available to corporations, professional associations, and other organizations. For details and discount information, contact the special sales department of Stanford University Press. Tel: (650) 723-9434, Fax: (650) 725-3457. 
To all of those people I have been fortunate to meet during my various sojourns and who tolerated my personal CQ limitations.

-P.C. EARLEY

S.D.G.- who maketh us the same yet different.

-S. ANG 
